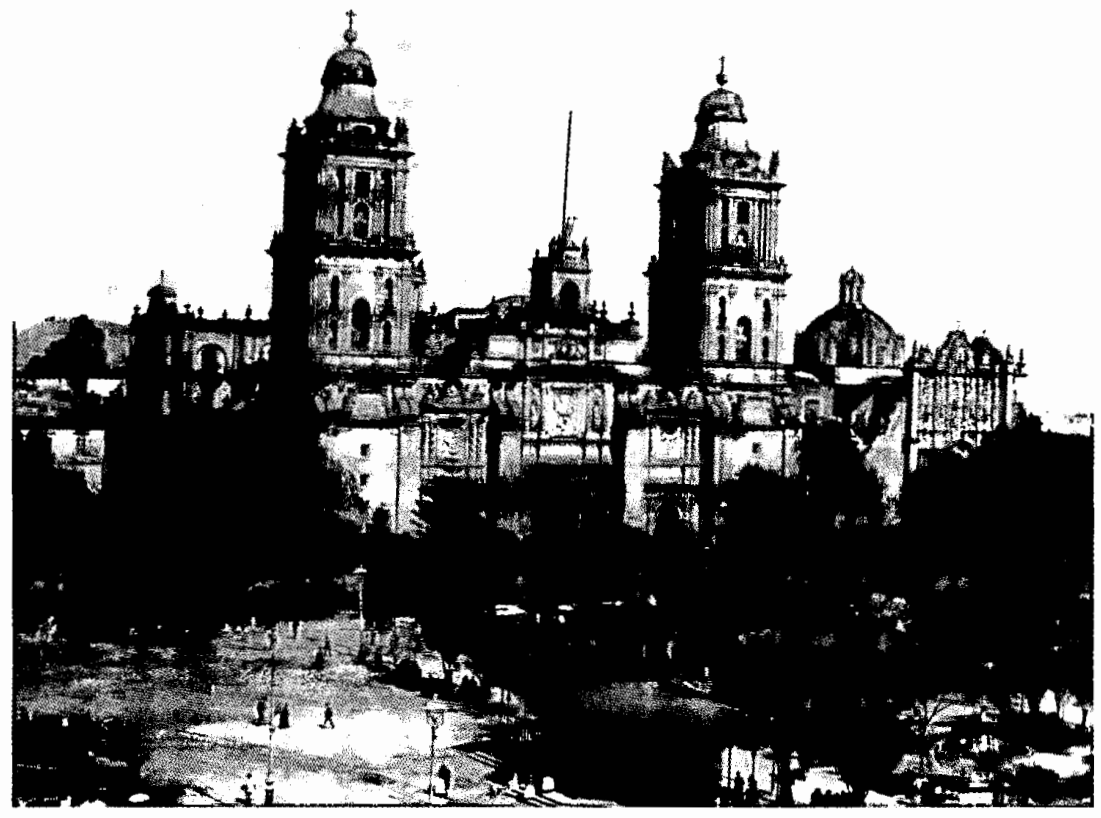




\section{Jorge Victoria Ojeda}

Licenciatura y maestría en Ciencias Antropológicas por la Universidad Autónoma de Yucatán. Ductor en Antropología por la UNAM. Investigador del Archivo General del Estado de Yucatán (AGEY). Sus áreas de investigación son: fortificaciones en la península de Yucatán y el Caribe, contrabando, los negros en la península yucateca e historia novohispana de Yucatán en general. Pertenece al Sistema Nacional de Investigadores del CONACYT. Entre sus publicaciones destacan La escultura del siglo XVI en Yucatán. El caso del Cristo indigena de Mani (1993); Mérida de Yucatán de las Indias. Piratería y estrategia defensiva (1995), y El desplazamiento arquitectónico defensivo en el Campeche colonial (2000). Premio Hispanoamericano de Ensayo Histórico 2002.

\section{Resumen}

El artículo se ocupa de Jean François, uno de los principales caudillos esclavos de la revolución haitiana quien desempeñó un papel importante en la contienda armada desarrollada en la isla de La Española. Primero se sublevó en unión de otros esclavos, buscando la libertad y proclamando la monarquía francesa; posteriormente España lo ganó para su causa, dejándose Jean François llevar por intereses personales y olvidando sus antiguos ideales de libertad general. Terminó sus días en un exilio forzado, sin que la corona hispana cumpliera las promesas ofrecidas.

\section{Palabras clave:}

Haití, revolución haitiana, caudillo negro.

\section{Abstract}

This article deals with Jean François, one of the main slave leaders of the Haitian revolution who played a key role in the armed struggle on the island of Hispaniola. First he rose up, together with other slaves, seeking freedom and proclaiming the French monarchy and subsequently he was won over by Spain to fight for her cause, driven by personal interest and forgetting his former ideals of general freedom. He ended his days in forced exile, after the Spanish Crown had failed to fulfill its promises to him.

Key words:

Haiti, Haitian revolution, Black leader.

Fecha de recepción: enero de 2003

Fecha de aceptación: marzo de 2003 


\title{
Jean François. De la revolución haitiana a su exilio en España
}

\author{
Jorge Victoria Ojeda
}

\section{INTRODUCCIÓN}

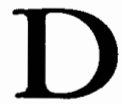
e los actores iniciadores de la revolución haitiana, los historiadores siempre han preferido abordar la figura del libertador ToussaintLouverture, sin duda por tratarse de un combatiente encasillado en el panteón de los héroes patrios. Esa preferencia ha eclipsado a otros participantes de esa contienda rebelde cuyas historias ayudarían a comprender lo acontecido en Saint Domingue, en la parte española de la isla; en los intereses de la metrópoli hispana en torno a lo que acontecía al otro lado del océano, y en la postura que la corona española mantuvo hacia sus antiguos aliados negros una vez firmada la paz de Basilea.

Las presentes líneas tratan sobre la vida de Jean François, conocido en el bando español como Juan Francisco, uno de los principales líderes negros del movimiento rebelde entre los años 1791-1793, y aliado de España contra la Francia revolucionaria en la lucha desarrollada en La Española de 1793 a 1795 . Tal vez esta condición haya influido en su olvido en las páginas de las historias de la revolución y de España. En ese último año la vida de Juan Francisco tomó un giro diferente, y de forma casi obligada se lo trasladó del Caribe a la península ibérica en el marco de una actitud hacia él, por parte de la corona, un tanto diferente a las complacencias de que había disfrutado durante sus años de combatiente en la contienda franco-hispana.

En líneas abajo se apuntan las aproximaciones referentes a Jean François, abarcando su probable origen; su participación en el inicio del movimiento rebelde; el papel que desempeñó como combatiente por la reinstalación de la monarquía en Francia, concluyendo con su paso a las filas del bando hispano para luchar por España en la persecución de sus intereses por recuperar la isla.

\section{SUS ORÍGENES}

Como en el caso de la mayoría de los esclavos negros de las plantaciones de Saint-Domingue, Jean François era de procedencia africana sin conocerse su ascendencia tribal. Las regiones del África exportadoras de fuerza de trabajo esclava para la explotación de las riquezas del suelo de la colonia francesa fueron específicamente Senegal, Guinea, Nigeria y el Congo, ${ }^{1}$ aunque esta última tuvo la primacía. ${ }^{2}$

'Franco, Documentos, 1954, pp. 21-22.

${ }^{2}$ Geggus, Slavery, 1982, p. 442, señala que la mayoría de los negros de la colonia habían naciclo en el Congo o en la misma isla. 
Jean François, o bien Ana, ${ }^{3}$ su madre, pudo provenir de cualquiera de esas regiones del "continente negro" que aportaron al nuevo mundo aproximadamente 7000000 de esclavos durante el siglo XVIII, de los que unos 30000 fueron llevados a Saint Domingue para trabajar en los plantíos de caña de azúcar y otros cultivos. $^{4}$

Mencionado más de una vez como etíope, ${ }^{5}$ James señala a Jean François como cimarrón al momento del inicio del levantamiento armado de 1791. Añade que era nativo de Santo Domingo (¿Saint Domingue?) y lo describe como "atractivo", con excepcional inteligencia, bravo, soberbio y tenaz. ${ }^{6}$ De similar manera, Korngold apunta que el caudillo negro era de carácter altanero y poseía un elocuente discurso.?

El nombre de Jean François pudo ser una autodesignación al comenzar el mo-

\footnotetext{
${ }^{3}$ Relación de los oficiales negros procedentes de las tropas auxiliares de Santo Domingo. Cádiz a 4 de abril de 1796, en Archivo General de Indias (en adelante AGI), Estado, 3, núm. 10 (5c).

${ }^{4}$ Sheridan, "Plantation", 1969, p. 15; Rodríguez, "Emancipación", 2001, p. 47.

${ }^{5}$ El gobernador García señalaba, tal vez sin fundamento, que los jefes del movimiento revolucionario de Saint Domingue eran etíopes. Carta de Joaquín García al rey. Santo Domingo a 22 de abril de 1793, en Archivo General de Simancas (en adelante AGS), Secretaría de Guerra (en adelante SG), leg. 7157, 19, núm. 113.

${ }^{6}$ James, Black, 1982, p. 93. Agrega que el carácter altivo de Jean François lo llevó a escapar de su amo y quedar como cimarrón hasta antes del estallido de la rebelión.

${ }^{7}$ Korngold, Citizen, 1979, p. 116. Otros autores siguen mencionando lo referente a la personalidad orgullosa y altanera de este rebelde, por ejemplo, Ott, Haitian, 1973, p. 41.
}

vimiento rebelde. Sin embargo, si Jean François, más conocido como Juan Francisco al pasarse a la filas españolas, firmó únicamente con ese nombre durante los años de la guerra y algunos de su estancia en Cádiz, para mayo de 1803 el ya antiguo jefe de los rebeldes firmaba como Jean François Petecou al inicio y calce de una carta dirigida al gobernador de Cuba. ${ }^{8}$ Hasta ahora es la única referencia que hemos encontrado donde se lo menciona con apellido, el cual fue también autoimpuesto en un intento por integrarse a la nueva sociedad donde vivía. La palabra francesa Petecou significa en castellano "rompecuellos", lo que pudiese hacer referencia a su belicosidad.

Por otro lado, es incierto si Jean François, a similitud de otros caudillos como George Biassou, Hyancinthe, Toussaint Louverture o Jean Dessalines, era seguidor del vudú. Al menos un investigador señala a Jean François y a Biassou como profesantes de la religión católica al comienzo del movimiento armado. ${ }^{9}$ Franco señala que los convocados a la noche del 15 de agosto eran "delegados de diversas plantaciones y talleres", omitiendo si eran o no practicantes de ese sincretismo religioso. ${ }^{10}$ En el mismo sentido, si a la muerte del sacerdote iniciador, el mando del movimiento rebelde pasó a manos de Jean François y Biassou, ${ }^{11}$ la sucesión pudo deberse por sus nexos con el vudú y porque ambos fuesen sacerdotes de importancia.

\footnotetext{
${ }^{8}$ Carta de Juan Francisco Petecou. Cádiz a 10 de mayo de 1803 , en AGI, Estado, 3, núm. I0.

${ }^{9}$ Benot, Révolution, 1987, p. 139.

${ }^{10}$ Franco, Documentos, 1954, pp. 22-23.

${ }^{11}$ Ibid., p. 24; Di Tella, Rebelión, 1984, p. 72.
} 
JEAN FRANÇOIS EN LA REBELIÓN DE LOS ESCLAVOS NEGROS

\section{El esclavo sublevado}

Poco después de una ceremonia en Bois Caiman los esclavos se insurreccionaron en la parte norte de Saint Domingue la noche del 22 de agosto de 1791 en busca de su libertad o, mejor dicho, en contra de la opresión ejercida sobre ellos por los esclavistas de la isla. En esa ocasión ardieron varias plantaciones en Plaine du Nord, cerca de Le Cap, como presagio de lo que seguiría ocurriendo en los demás campos rebelados. El cabecilla de ese movimiento era Boukman, secundado por Jean François, Biassou y Jeannot. ${ }^{12}$ Estos personajes han sido señalados como dirigentes de bandas de cimarrones, sin embargo, no existen pruebas concluyentes sobre ello. ${ }^{13}$

A los pocos días de iniciada, la rebelión había alcanzado proporciones inimaginables, incitada, sobre todo, por la idea de tres días de asueto concedida a los esclavos por el soberano francés pero no respetada por los amos de la colonia antillana. ${ }^{14}$ Además de los sucesos del norte en Acul y Limbé, donde se encontraban los caudillos señalados, por el oeste los trabajadores de las plantaciones se sublevaron al mando de pequeñas partidas dirigidas

\footnotetext{
${ }^{12}$ Franco, Documentos, 1954, p. 23; Di Tella, Rebelión, 1984, p. 71.

${ }^{13}$ Geggus, Slave, 1983 , p. 10.

${ }^{14}$ El levantamiento armado de los esclavos pudo tener este pretexto, tal como se apunta en los expedientes consultados; sin embargo, como bien señala Knight, "Haitian”, 2000, p. 35, los orígenes de la revolución haitiana "provienen de los cambios más amplios ocurridos en el mundo atlántico durante el siglo Xvil".
}

por Hyacinthe, entre otros; de igual forma, por el sur los insurrectos arrasaban pueblos y amedrentaban a la ciudad de los Cayos. ${ }^{15}$

Sobre los sucesos ocurridos en el norte de la colonia vecina, el gobernador de la parte hispana de La Española, Joaquín García, informaba a la metrópoli que

la noche del 22 al 23 de agosto [...] se manifestó en las inmediaciones del Guárico l...] una sublevación de los negros esclavos, algunos mulatos libres y blancos [...], dando principio con el hecho [...] de incendiar las habitaciones azucareras, matando a todo hombre blanco y proclamando la libertad.

García no omitía su desconcierto y la actitud a tomar ante la situación de la colonia francesa, aunque ya había dictado precauciones en la frontera con aquélla. ${ }^{16}$ Estas prevenciones se cimentaban en el temor de que los rebeldes y mulatos perdiesen la guerra contra Francia y se refugiasen en territorio español, con la posibilidad de influir con sus ideas a los esclavos de esa colonia. El rey ordenó entonces a García girar instrucciones a las posesiones españolas más cercanas a Santo Domingo para que estuviesen prevenidas en caso de solicitarles ayuda. ${ }^{17}$

La cerrazón de los plantadores blancos franceses, que se negaron a aceptar la igualdad social y política de los mulatos

${ }^{15}$ Franco, Documentos, 1954, p. 24.

${ }^{16}$ Informe de García al conde del Campo de Alange. Santo Domingo, en septiembre de 1792, en AGS, SG, leg. 71.49, núm. 439.

${ }^{17}$ Consejo de Estado en Aranjuez a 16 de abril de 1792, en AGS, SG, leg. 7150, núm. 209. A Santiago de Cuba y Puerto Rico se les indicó que preparasen una tropa competente y a Nueva España recursos económicos. 
y negros libres, llevó a numerosos libertos a unirse a la sublevación de los esclavos, con lo que el movimiento creció en poderío numérico, llegando a controlar grandes sectores, sobre todo al norte y al oeste de la colonia. ${ }^{18} \mathrm{El}$ mando de la insurrección esclava sufrió un cambio al poco tiempo de iniciada debido a la muerte de Boukman en el mes de noviembre, durante un ataque a Le Cap. El mando del movimiento recayó en Jean François, Biassou y Jeannet. ${ }^{19}$ Franco señala que a Biassou, inculto, pero no falto de valor y audacia, se sumó Toussaint Louverture en calidad de secretario, y que desde meses antes participaba activamente en los preparativos revolucionarios. ${ }^{20}$

\section{Jean François, defensor del rey de Francia}

Poco después de iniciado el movimiento, enarbolando la bandera y la lucha por la causa del rey de Francia, los rebeldes negros se autonombraron con pomposos títulos: Jean François, gran almirante de Francia; George Biassou, virrey de las regiones conquistadas y de los ejércitos del rey; y Toussaint, médico de los ejércitos del rey de Francia. ${ }^{21}$ Geggus señala que

18 Joaquín García al conde de Campo de Alange. Santo Domingo, 25 de noviembre de 1791, en AGS, SG, leg. 7150, núm. 206.

${ }^{19}$ Franco, Documentos, 1954, p. 24; Di Tella, Rebelión, 1984, p. 72. Por su parte, Otts, Haitian, 1973 , p. 41 , apunta que después de la muerte de Boukman, Jean François fue el más importante de ese grupo de líderes.

${ }^{20}$ Franco, Documentos, 1954 , pp. 24-25.

21 Aimé, Toussaint, 1967, p. 243; Schoelcher, Vie, 1982, p. 104 . El nombramiento de gran almirante contrastaba con el combate en tierra que realizaba este negro, ya que ese título se relaciona con el
Jean François tomó el título mencionado poco después del inicio de la revuelta y que tanto él como su esposa fueron elevados por los negros rebeldes al rango de rey y reina. ${ }^{22}$

A pesar de la magnitud del alzamiento no todo fue victoria en su derrotero, ya que sufrieron un fuerte contraataque en la parte norte y perdieron su principal fortaleza, Le Coq, a manos de la guarnición de Port-de-Paix y de las tropas del cordón oeste; asimismo, los militares Cambefot y De Touzard recuperaban Acul y desembarcaban en Port-Margot, respectivamente. ${ }^{23}$ Ante estas circunstancias, la fe de los negros en el movimiento vaciló, y los jefes pensaron en la sumisión, aunque, según un testigo presencial, poco después de un viaje de Jean François a la parte española de la isla hubo cambios en la estrategia a seguir. ${ }^{24}$

Ante los acontecimientos ocurridos en su colonia, en noviembre de 1791 Francia envió a los comisarios Roume, Mirbeck y Saint-Leger para tratar de restablecer el orden en Saint Domingue. El último comisario entabló comunicaciones con los rebeldes, por lo que Jean François y Biassou enviaron a dos negros libres, Raynal

mar, Biblioteca Nacional de Madrid (en adelante BN), Mss. Sig. 2979, f. 91, serie Historia de los virreyes.

${ }^{22}$ Geggus, "Slave", 1997, p. 145. liste dato no lo hemos encontrado apuntado en ningún expediente consultado.

23 Aimé, Toussaint, 1967, pp. 244-245.

${ }^{24}$ Di Tella, Rebelión, 1984, p. 73. Este autor comenta que el testigo presencial, M. Gros, cayó prisionero de los sublevados y tuvo la oportuniclad de ver a un grupo de oficiales españoles compartir la mesa con los jefes negros. Sin embargo, apunta que: "No se puede saber en qué medida dar crédito a este informe." 
y Duplessis, a notificar a los blancos sus disposiciones conciliadoras. Entre otras cosas, el mensaje firmado por Jean François, Biassou, Toussaint y los mulatos Desprez, Manzeau y Aubert, trataba de las disposiciones de igualdad de derechos civiles para las personas libres de la colonia. ${ }^{25}$ Como única respuesta a esta misiva, la Asamblea Colonial tuvo hacia los negros una contestación insultante, lo que provocó la desesperación y la cólera de los rebeldes. ${ }^{26}$

Ante esos sucesos la situación entre los distintos bandos no mejoró, y alboreando el nuevo año, las hostilidades se reanudaron. El día 15 de enero de 1792 Jean François atacó y tomó la población de Ouanaminthe; por su parte, Biassou fracasó en su intento de apoderarse del Cabo la noche del $22 .{ }^{27}$ En una misiva del 25 de enero, el gobernador García señalaba que, ante la irritación de los negros por lo sucedido con los colonos blancos, los rebeldes arrasaban todo a su paso. ${ }^{28}$

En marzo de ese año, el gobernador García señalaba que hasta ese momento los rebeldes habían respetado el territorio español, "y dan pruebas de mirar a la corona en sagrado que veneran", tal vez con intenciones de solicitar refugio en caso de que perdieran la guerra. Ante esta posibilidad solicitaba al rey las disposiciones a seguir. $^{29}$ Durante la segunda mitad de

${ }^{25}$ Aimé, Tonssaint, 1967, pp. 246-247.

${ }^{26}$ Franco, Documentos, 1954, p. 25.

${ }^{27}$ Ibid., pp. 25-26.

${ }^{28}$ Informe de García al conde de Campo de Alange, fechado en Santo Domingo el 25 de enero de 1792, en AGS, SG, leg. 7150, núm. 207.

${ }^{29}$ Joaquín García al conde de Campo de Alange. Santo Domingo a 23 de marzo de 1792, en AGS, SG, leg. 7150 , núm. 216.
1792 los negros sublevados del norte recurrieron abiertamente a las autoridades de la parte española de la isla solicitándoles su apoyo en material bélico, ropas y víveres, con lo que las tropas enemigas, según ellos, "no resistirían dos meses". Ante la petición de Jean François, García contestó que la resolución y ayuda no correspondían al gobierno español. ${ }^{30} \mathrm{El}$ cabecilla negro reiteró su solicitud señalando que luchaban por la monarquía francesa, pero debido a su lejanía, y con esperanza de cooperación, recurtían "a su cohermano de España". De nueva cuenta la respuesta fue negativa. ${ }^{31}$

Los caudillos negros se dirigieron entonces al arzobispo de Santo Domingo, Fernando Portillo y Torres, preguntándole sobre la posibilidad de escribirle al rey de Francia mediante Joaquín García. Asimismo, apuntaban que ofrecían hablar con los emisarios españoles que fuesen a ellos y que de los asuntos a tratar no se daría razón a los demás negros que los seguían. Los rebeldes proponían mandar a los esclavos combatientes a sus lugares de trabajo en calidad de libres a cambio de algún salario por día o semana para que de ese modo los blancos pudiesen reducirlos de nueva cuenta a un estado "que les parezca a su esclavitud". Agregaban que, aunque no quisieran vivir siempre en guerra, por el momento no era posible desarmar a los otros negros sino hasta

${ }^{30}$ Cartas del gobernador de Santo Domingo, con varios documentos relarivos a las ocurrencias y rebeliones de los negros de la parte francesa, del 7 de enero al 25 de diciembre de 1792 ( 25 dé septiembre), en AGS, SG, leg. 7157, exp. 18.

${ }^{3}$ Carta de Jean François al gobernador de Santo Domingo. Juana-Méndez a 13 de febrero de 1793, en AGs, SG, leg. 7157, exp. 19, núm. 110. 
después de que estuvieran destinados a otros sitios, ya que temían por sus vidas y sospechaban que, como jefes del movimiento, el gobernador los entregase a los franceses como sucedió con el mulato Ogé años antes. Por último, reiteraban "que la insurrección comenzó en nombre del rey [de Francia], haciéndoles saber que eran libres y que tomaban las armas por su rey". ${ }^{32}$

El contenido de esta carta denota que los rebeldes aceptaban su fidelidad al soberano francés y que las peticiones de libertad general eran simulaciones para esconder sus intereses personales. Geggus señala que la desilusión e impotencia reinaban entre los jefes negros al grado de que Jean François y Toussaint ofrecieron secretamente vender a sus seguidores y ver la esclavitud restaurada, si ellos conseguían su libertad..$^{33}$ Estas y otras acciones despertaron sospechas entre los combatientes de Jean François e incluso, al encontrarse en el bando español, hubo deserciones de su tropa alegando que su jefe los mantenía engañados. ${ }^{34}$

Por otra parte, con la intención de hacer saber a las autoridades españolas su valentía y coraje -características que aquéllas podían aprovechar en su beneficio-, Jean François envió una nota al gober-

${ }^{32}$ Consulta de Juan Francisco, general, Toussaint y otros jefes si podrían escribir al señor presidente, s. d.; en AGS, sG, leg. 7157 , exp. 18, núm. 50 . Copia de petición de los jefes negros dirigida al arzobispo, s. d. ('septiembre de 1792?), en AGI, Santo Domingo, leg. 1110 .

${ }^{33}$ Geggus, Slavery, 1982, p. 63.

${ }^{34} \mathrm{El}$ gobernador de Santo Domingo da cuenta de la deserción de algunos miembros de la tropa de Juan Francisco. Santo Domingo a 18 de febrero de 1794, en AGS, SG, leg. 7157, exp. 20, núm. 245. nador García en la que decía haber tomado un campo de blancos y donde "maté muchos, yo os envío la gola del jefe de campo, cuya cabeza tengo aquí, yo os suplico de devolverme la gola cuando la haya visto". 35

Las acciones de campaña de Jean François ya habían dejado huella en los intereses de García, quien no ocultaba su admiración hacia un negro que, ignorante de todo asunto de la milicia, mantenía en jaque a las tropas de Saint Domingue. En misiva a Pedro de Acuña le indicaba que cuando aquéllas atacaban al jefe de color sus seguidores tomaron las armas y

con igual empeño, se fortifica y acerca sus soldados en términos de hacer una vigorosa defensa [...] rechaza con escarmiento a las fuerzas que contra él deben dirigirse. Una de sus primeras disposiciones ha siclo pegar fuego a la pocas casas y haciendas que habían quedado en el llano del Guárico, sin perdonar el más pequeño bohío 0 albergue de los negros reduciéndola a escombro y ceniza para observar las operaciones de las armas francesas, y que no tengan dónde poderse alojar, ni dónde resistir el rigor del sol, ni liberarse de la grande humedad de las noches: máxima de un sujeto de más conocimientos y pericia militar que la que se le supone a un negro cuya ocupación ha sido la labor de la tierra. ${ }^{36}$

A comienzos de 1793, García reiteraba la consulta sobre la actitud que debía tomar ante la petición de los negros y re-

${ }^{35}$ Carta de Juan Francisco a García. Septiembre 30 de 1792, en AGS, SG, leg. 7157, exp.18, núm. 59.

${ }^{36}$ Carta de García a Pedro de Acuña. Santo Domingo a 25 de octubre de 1792, en AGS, SG, leg. 7157, exp. 18. 
comendaba halagarlos y satisfacerlos en lo posible, ya que, ante una probable enemistad con su vecino, aquél podría atraerlos para hacerles la guerra. ${ }^{37} \mathrm{Su}$ posición personal tal vez ya estaba definida desde antes, pues no ocultaba su temor de que la libertad de los negros de la colonia contigua pudiese ocasionar serios trastornos en las colonias españolas, asunto que le señalaba al conde de Alange de la siguiente manera:

Con mayor calor se habla en el Guárico de dar libertad a todos los negros y expatriarlos para que éstos lleven la mecha en una mano y en la otra la revolución por todo el nuevo mundo, y conseguir o poner en ejecución las pérfidas ideas que en los primeros momentos de la revolución francesa se manifestaron en sus sediciosos papeles públicos. ${ }^{38}$

El 27 de marzo de ese año los ternores de rompimiento se hacían realidad con la decisión de España de declararle la guerra a Francia, expidiéndose la real cédula al respecto el 30 del mismo mes. ${ }^{39} \mathrm{Sin}$ embargo, poco antes el monarca español había hecho saber sus intereses por medio de real orden del 22 de febrero, en la cual incitaba al gobernador de Santo Domingo a

37 Informe de García a Campo de Alange. Santo Domingo a 12 de marzo de 1793, en AGS, SG, leg. 7150 , núm. 313.

${ }^{38}$ Cartas del gobierno de Santo Domingo dando cuenta de lo ocurrido en aquella isla con motivo de la rebelión de los negros. Santo Domingo a 13 de enero de 1793, en AGS, SG, leg. 7157, exp. 19, núm. 83.

39 Decreto declarando la guerra a la Francia en 1793. Aranjuez a 23 de marzo de 1793, en Archivo Histórico Nacional (en adelante AHN), Estado, leg. 883, núm. 4, caja 2. ganar el ánimo de Juan Francisco [Jean François] y Jacinto [Hyacinthe], y demás jefes aliados [...] para que hostilicen a la tropa y habitantes de la parte francesa adictos a la nueva constitución hasta lograr su total exterminio y reunirla a nuestra tierra, para lo cual les franqueará vuestra señoría los auxilios posibles, ofreciéndoles, desde luego, que su majestad los recibe bajo de su real protección, y asegura bajo su real palabra a los negros y mulatos desde ahora para entonces la libertad, excepciones, goces y prerrogativas correspondientes a vasallos suyos, y a éstos y a los blancos ventajosos establecimientos en aquella parte o en la Española . ${ }^{40}$

\section{Juan Francisco bajo las banderas reales de España}

Una vez recibido en Santo Domingo el mandato del rey, García dio órdenes al comandante de la banda del norte, Gaspar. Cassasola, para que localizara a Juan Francisco; al comandante de la banda del sur, coronel Cabrera, para que contactase con Biassou, y a Ignacio Caro, teniente del batallón fijo de la plaza, para que hiciera lo mismo con Jacinto, solicitando a su vez de los negros que indicasen las fuerzas físicas con las que contasen, así como sus municiones y, por supuesto, sus necesidades. García no ocultaba su alegre interés ya que decía esperar las respuestas de los líderes negros "con ansia y desvelo". 41

En misiva del 11 de agosto, José Vázquez, cura de Dajabón, señalaba al arzo-

${ }^{40}$ El gobernador de Santo Domingo contesta la Real Orden de 22 de febrero. Santo Domingo a 25 de abril de 1793, en AGS, SG, leg. 7157, exp. 19, núm. 117.

${ }^{41}$ Ibid. 


\section{SECUENCIA}

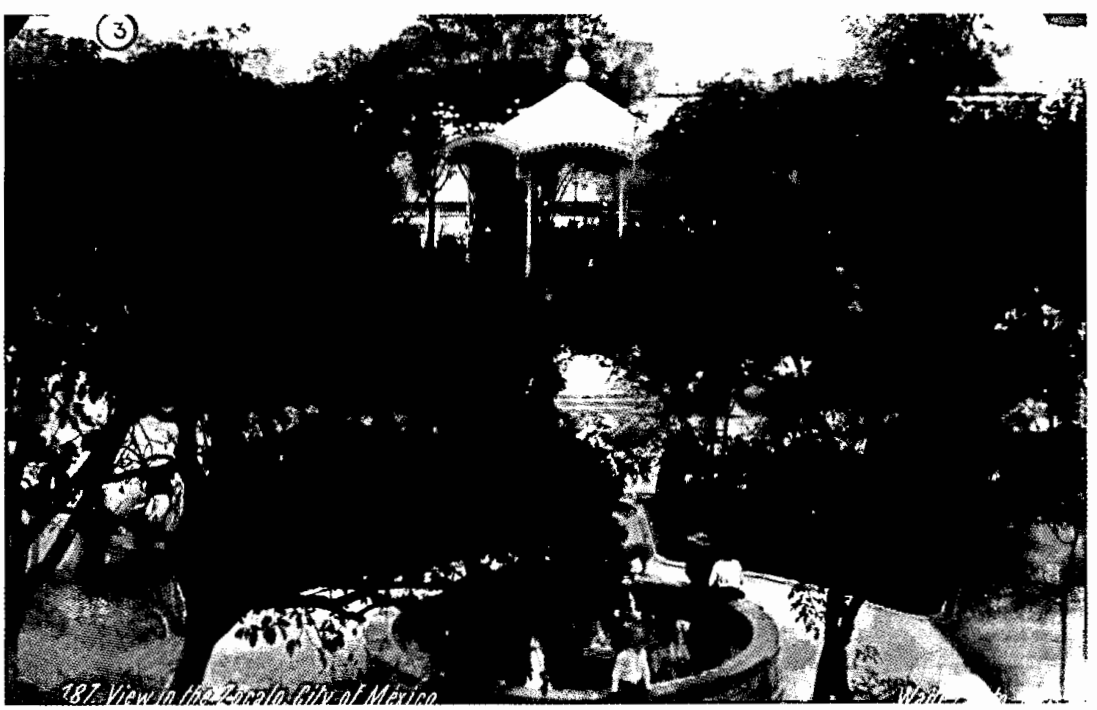


bispo que meses atrás le había entregado en mano a Juan Francisco la carta de invitación a la adhesión, haciéndosela traducir. Ante la respuesta del negro rebelde el notificante infería que no había duda alguna sobre "su amor hacia el rey de España" y a los principios cristianos, ya que ahora formaba parte de las fuerzas españolas. ${ }^{42}$

Existe la opinión de que fueron los esclavos insurrectos quienes solicitaron el apoyo de la corona española, a la vez que se ofrecieron gustosos para apoyarla en sus intereses. ${ }^{43}$ Esta idea se deriva, por un lado, de una carta de Hyacinthe al gobernador García en la que le señalaba que era partidario del rey, por lo que pedía asilo; ${ }^{44}$ por el otro, de una misiva que en febrero 13 de 1793 Juan Francisco escribió a Joaquín García proponiéndole "un negocio interesante": le solicitaba municiones, armas de fuego y blancas, telas para el vestuario de su tropa y algo de víveres a cambio de que si ganaban la guerra contra los "hombres blancos", estarían todos bajo el dominio del soberano de España "y nos hará trabajar como debe de ser siendo sus súbditos". 45

Como sea que haya sido el asunto, el resultado fue que las tropas negras y las

${ }^{42}$ Copia de la carta del vicario de Dajabón al arzobispo de Santo Domingo. Agosto 11 de 1793, en AGI, Santo Domingo, leg. 111.0, la respuesta de Juan Francisco fue escrita en francés el 8 de agosto. De Juan Francisco en que promete subordinación, agosto 8 de 1793, en AGI, Santo Domingo, leg. 1110.

${ }^{43}$ Porro, "Inquietudes", 1993, pp. 73-74.

${ }^{44}$ Copia traducida de una carta de Hyacinthe a García. Sin fecha, en AGS, SG, leg. 7157, exp. 19, núm. 109.

${ }^{45}$ Carta de Juan Francisco a Joaquín García. Valiere a 13 de febrero de 1793, en AGS, SG, leg. 7157, exp. 19. fuerzas españolas se aliaron con un supuesto fin único, pero lo cierto fue que cada uno buscaba satisfacer sus propios intereses. De esa unión los blancos fueron, al parecer, los que demostraron mayores desconfianzas hacia sus nuevos compañeros de aventura.

Tras la admisión de los caudillos y sus seguidores en el bando hispano, los rebeldes pasaron a ser conocidos con el nombre de Tropas Auxiliadoras, Negros Auxiliadores o Negros Auxiliadores de Carlos IV, sin por ello llegar a formar parte de las milicias españolas. El cambio a favor. de los intereses hispanos significó también la castellanización del nombre de Jean François, conocido ahora como Juan Francisco, el de George Biasssou por Jorge, manteniendo el "apellido", y Hyacinthe por Jacinto. ${ }^{46}$

La alianza entre rebeldes y españoles de inmediato resultó beneficiosa a los segundos, ya que pasaron a ocupar la parte del territorio francés que desde 1791 estaba bajo el control de los insurgentes. Para agosto de 1793 los españoles y sus auxiliares ocupaban en el norte las zonas de Vailleère, Trou, Fort-Dauphin, Grande-Rivière, Ouanaminthe, Marmelade, Ennery, Plaisance, Gonaives y Limbé. ${ }^{47}$

${ }^{46}$ Jacinto, el jefe de la parte de Neyba fue asesinado el 16 de agosto de 1793 después de ser invitado por los mulatos a un desayuno. El gobernador de Santo Domingo comunica la noticia del funesto fin que tuvo el negro Jacinto. Santo Domingo a 13 de septiembre de 1793, en AGS, SG, leg. 7157, exp. 19.

${ }^{17}$ Franco, Documentos, 1954, p. 28; Franco, Historia, 1971, p. 229. Cabe señalar que en estas dos obras se comete el mismo error al señalar que en 1791 los españoles y auxiliares ocuparon las mencionadas regiones, siendo en realidad al año siguiente. En Franco, Rebeldias, 1975, p. 9. 
Sin embargo, desde meses antes Juan Francisco ya había comenzado a proceder contra los ahora enemigos, "negros brigantes" que se introducían por el lado de Guava y Atalaya para practicar el abigeato. ${ }^{48}$

En esta última región se tuvo una victoria frente a un ejército de 7500 franceses y mulatos, y en la toma de Mermelada se logró la victoria con el resultado de 1000 franceses muertos. ${ }^{49}$ Aquellos éxitos hicieron pensar al arzobispo de Santo Domingo que la guerra sería favorable para España. Sus erradas esperanzas las señalaba de la manera siguiente: "no tardaremos en ser dueños de la colonia, y entonces podremos decir que Dios, desde los cielos, se ha dignado ponerla en nuestras manos". Sin embargo, también hacía la reflexión, un tanto temerosa, de que sus destinos y vidas dependían de la fidelidad de "esos pobres negros". ${ }^{0}$ Entusiasmado por el derrotero de la contienda, el arzobispo Portillo y Torres fundaba sus anhelos en aquéllos e, incluso, de Juan Francisco señaló "que el talento, y firmeza de espíritu, y tesón en llevar a cabo sus resoluciones, después de maduramente tomadas, adornan y distinguen a este negro entre millones de su color". ${ }^{51}$

$\mathrm{Al}$ religioso le inquietaba lo que sucedería si se decretaba la libertad para todos

${ }^{48}$ Carta del arzobispo de Santo Domingo a don Pedro de Acuña. Santo Domingo, 25 de mayo de 1793, en AGI, Santo Domingo, leg. 1110.

49 Relación de la toma de la Mermelada el 28 de julio y el papel de Toussaint. Santo Dorningo a 12 de agosto de 1793, en AGS, SG, leg. 7157, exp. 19, núm. 189.

${ }^{50}$ Carta del arzobispo de Santo Domingo a don Pedro de Acuña. Santo Domingo, 25 de agosto de 1793, AGI, Santo Domingo, leg. 1110.

${ }^{51}$ Ibid. los negros en la colonia francesa, lo que, en su opinión, podría hacer inhabitable la isla. Como paliativo a ese suceso llegó al extremo de proponer a las autoridades metropolitanas que en la parte española de la isla se "dispensara esta gracia por mano y boletín de Juan Francisco, suponiendo no lo daría sino a gente armada, y a sus órdenes"; en otras palabras, únicamente lograrían la libertad aquellos que el general negro avalara como dignos y útiles. El inconveniente que el arzobispo veía en su propuesta era la unión de los que no lograsen la libertad y su posible levantamiento. Sin embargo, el religioso mantuvo su idea original, ya que, según él, era mucho más de temer el hambre y el robo que ocasionaría la inacción de los negros libres en el territorio, lo que podía ser incontrolable por el mismo Juan Francisco "o por nosotros". Agregaba que quienes no obtuviesen esa gracia del líder negro no serían peligrosos, ya que por estar "desarmados, desvalidos, e inútiles no pueden habilitarse por los franceses", porque no les servían en esas condiciones; entonces sería fácil su derrota por el jefe de los auxiliares. Del mismo modo, las personas liberadas serían remitidas a los ingenios y al cultivo de la tierra, "lo que a nosotros resultaría quizá el mayor [beneficiol de no tener tanto que darles para subsistir y militar". El reverendo concluía que García pondría en práctica su idea si no ocurriese antes un mayor inconveniente, y recalcaba que su proyecto fue del agrado del rey. ${ }^{52}$

La propuesta de Portillo y Torres resulta interesante para conocer los planes que las autoridades españolas tenían sobre Juan Francisco, pues si por una parte le

$$
52 \text { Ibid. }
$$


resultaría halagador al negro que por medio de su persona se otorgase la gracia de la libertad (algo que correspondía al rey o a quien él designase para ello), con lo que creerían asegurar su fidelidad, por la otra, el hecho podría dividir a la gente de color, ya que los esclavistas no serían entonces los españoles sino Juan Francisco y sus allegados.

En la misma misiva de 1793, el arzobispo indicaba a Pedro de Acuña que Juan Francisco había solicitado a las autoridades españolas la formación de un ejército compuesto por 12000 hombres. A ello el religioso señaló que, si bien el aliado auxiliar había dado muestras de adherencia a la "nación", serían demasiadas confianzas armarle más gente de la existente en el propio ejército de Santo Domingo, sobre todo si "nuestra suerte, sucesos y fortuna" dependían de la buena voluntad, gratitud y correspondencia de Juan Francisco. Al caso, tampoco se omitía la probabilidad de que los franceses venciesen su voluntad y se uniese a ellos. ${ }^{53}$

Por otro lado, Juan Francisco también fue buscado por Francia con intenciones de reclutarlo en sus filas. Por medio de los comisarios civiles trató de alinearlo bajo la bandera republicana y apegarse a lo dictado sobre la libertad. ${ }^{54}$ España y Francia no fueron las únicas naciones que se fijaron en los insurgentes negros como piezas importantes del ajedrez político

${ }^{53} \mathrm{Ibid}$.

${ }^{54}$ Carta del arzobispo de Santo Domingo a don Pedro de Acuña. Santo Domingo, 25 de mayo de 1793, en AGI, Santo Domingo, leg. 1110. El gobernador de Santo Domingo instruye de las diligencias de los comisionados franceses para ganarse a los negros. Santo Domingo a 14 de julio de 1793, en AGs, leg. 7157, exp. 19, núm. 157. que se jugaba en el Caribe, pues Inglaterra también los exhortó a pelear bajo su bandera hasta el último momento de la estancia de los auxiliares en la isla, ofreciéndoles los mismos sueldos y mayores distinciones que las que gozaban hasta entonces. $^{55}$

Juan Francisco pudo utilizar la existencia de otras opciones de alianza como forma de presión ante los españoles para obtener beneficios. En algunos casos se desconoce el tono en que el jefe negro "solicitaba" ayuda a las autoridades, empero el señalamiento de García de que "atendiendo a los clamores repetidos de aquel negro y para que sigan fieles y sigan como ahora adictos a nuestro partido" le daría lo que solicitaba, ${ }^{56}$ deja entrever una fuerte dosis de chantaje.

A pesar de la unión entre ambos bandos, desde los primeros momentos los españoles se dieron cuenta de las rivalidades existentes entre los jefes negros a causa de la jerarquía que mantenían y los celos por el control. Biassou señaló a García que se consideraba cabeza del movimiento rebelde y acusaba a Juan Francisco de desear el liderazgo supremo sin cooperar en la lucha. Lo describía como hombre ambicioso, perverso, vanidoso, quimérico, de "grandes proyectos, muchas palabras, pero pocos hechos". Alegaba que él nunca

${ }^{55}$ Carta del regente de la Real Audiencia a su majestad, Santo Domingo a 22 de diciembre de 1795, en AGI, Santo Domingo, leg. 1033. Geggus, Slavery, 1982, pp. 181-182, señala que los ingleses y republicanos rivalizaron para ganar a las tropas de Juan Francisco.

${ }^{36}$ El gobernador de Santo Domingo da cuenta del envío de ropas a Juan Francisco. Santo Domingo a 7 de julio de 1793, en AGs, SG, leg. 7157, exp. 9, núm. 152. 
se dejó llevar por lo fastuoso, ni ofrecimientos generosos por parte de los comisarios civiles, mientras que Juan Francisco mantuvo conferencias con ellos, dando muestras de no ser persona de fiar. ${ }^{57}$

A su vez, Juan Francisco señaló al gobernador que él había probado su fidelidad a los españoles, pero que Biassou, "su segundo", había pensado perseguirlo y quitarle la vida, por lo cual pedía su arresto y que se le juzgara. García reflexionaba que ésta era una muestra más de los celos que existían entre aquellos jefes negros y el ansia por demostrar quién era superior. $^{58}$

Las autoridades respondieron que ellos habían siempre pensado que Juan Francisco era la autoridad y Biassou su segundo. ${ }^{59} \mathrm{~A}$ fines de ese año García señalaba que las desavenencias entre los dos negros cabecillas estaban ya arregladas, y agregaba que los sucesos entre ellos le había hecho ver "cuán embravecidos están estos negros [...] y cómo los arrastra la pasión a intentar hacer papel de grande distinción unos hombres que ayer gemían bajo el más duro yugo de la esclavitud". ${ }^{60}$

${ }^{57}$ Copia de un memorial dirigido por Biassou a García. San Miguel a 15 de julio de 1793, en AGs, SG, leg. 7157, exp. 12.

${ }^{58}$ El gobernador de Santo Domingo da cuenta de la conducta de Juan Francisco. Santo Domingo a 4 de septiembre de 1793, en AGS, SG, leg. 7157, exp. 19, núm. 194.

${ }^{59}$ El gobernador participa un envío del negro Biassou. Santo Domingo a 25 de septiembre de 1793, en AGS, SG, leg. 7157, exp. 19, núm. 208.

${ }^{60}$ Carta de García a Pedro de Acuña. Santo Domingo a 23 de noviembre de 1793, en AGs, sG, leg. 7157 , exp. 30; el gobernador informa que los generales Juan Francisco y Biassou están reconciliados de sus desavenencias. Santo Domingo a 14 de diciembre de 1793, en AGS, SG, leg. 7157, exp. 19, núm. 218.
Sobre los problemas entre los líderes encontramos la opinión de que Juan Francisco, Biassou y Toussaint

han fingido darse batallas entre ellos, engañando al general de la isla para que les suministrase municiones, armas y víveres, $y$ con nuestras mismas armas amenazan a las poblaciones a las cuales entran enarbolando la bandera española y piden carne para mantener a su gente y no por eso dejan de hacer atrocidades en nuestros dominios, robar y matar a los españoles que encuentran.

No en vano se decía que "más cuidado tienen con los negros nuestros aliados que con los enemigos declarados". ${ }^{61}$

Pero si las rencillas entre Biassou y Juan Francisco se resolvieron a instancias e interés de las autoridades, ${ }^{62}$ los problemas surgieron con Toussaint. A tal grado llegaron las intrigas que Juan Francisco consiguió a comienzos de 1794 alterar las buenas relaciones que Toussaint mantenía con las autoridades españolas, pensando incluso en asesinarlo. ${ }^{63}$

En cuanto a los grados militares que ostentaban los caudillos negros y que erradamente se piensa que España les respetó,

${ }^{61}$ Correspondencia sobre las ocurrencias de la isla de Santo Domingo con motivo de la guerra con los franceses. Año de 1796 (Memorial de don Gaspar de Cassasola, julio-agosto de 1794), en Instituto de Historia y Cultura Militar (en adelante II ICM), rollo 65, 5-4-11-1, f. 150.

${ }^{62}$ Previniendo de real orden que procure con prudencia y maña conciliar los ánimos de los jefes negros Biassou y Juan Francisco. Aranjuez a 1 de marzo de 1794, en AGS, SG, leg. 7159, exp. 11, núm. 40.

${ }^{63} \mathrm{El}$ gobernador de Santo Domingo hace referencia a la desunión que reina entre los jefes Biassou y Toussaint, Bayajá a 13 de abril de 1794, en AGS, sG, leg. 7159, exp. 61. Franco, Historia, 1971, p. 239. 
el marqués de Casa Calvo dejaba claro su origen al señalar que los negros "arbitrariamente" se los habían conferido, dejando entrever que el mantenimiento de aquellas designaciones como "gran almirante", "teniente general", "general en jefe del ejército" o "gran almirante y general de una parte de la isla de Santo Domingo" por parte de Juan Francisco, y de "mariscal de campo" por Benjamín, entre otros, "habían sido parte de las contemplaciones hacia los negros para atraerlos". ${ }^{64}$

El arzobispo también aprobó el reconocimiento de los títulos por las autoridades hispanas,

a lo que puede añadirse condecorar desde luego la persona como también el uniforme de Juan Francisco y sus principales, con todas las distinciones, y títulos brillantes, que parezcan convenientes (porque éstos se deshacen con la misma facilidad, si conviniere) para las fantasías de los negros, son sustancia estos títulos, y bastan para empeñarlos seriamente. ${ }^{65}$

Por otra parte, un suceso en la vida privada de Juan Francisco, suscitado al poco tiempo de pasarse a las filas españolas, fue su matrimonio con María Josefa. Presumiblemente la desposada haya sido la misma mujer que estuvo prisionera y que no fue intercambiada en su momento por los rehenes entregados por Toussaint,

64 Carta de Juan Francisco a García. Mayo 6 de 1793, en AGS, SG, leg. 7157 , exp. 19, núm. 136; de Juan Francisco de 8 de agosto de 1793 en que promete subordinación a los jefes subalternos del presidente. Dajabón, en AGI, Santo Domingo, leg. 1110.

${ }^{65}$ Carta del arzobispo de Santo Domingo a don Pedro de Acuña. Santo Domingo, 25 de mayo de 1793 , en AGI, Santo Domingo, leg. 1110. aunque en ese entonces se la mencionaba como su esposa, sin embargo, bien pudo ser otra la persona con la que contrajese nupcias y procreara dos hijas: María Josefa y Celestina. ${ }^{66}$ Para la ocasión, el cura Vázquez señaló que Juan Francisco "hizo trasladar [a] la contrayente a Dajabón a fin de precaverla de los accidentes de guerra, pidiendo permiso para realizar su contrato, y vivir con seguridad de su conciencia". ${ }^{67}$

José Vázquez señalaba que la boda se celebraría "el viernes o sábado", por lo que el miércoles esperaban al hermano de Juan Francisco. ${ }^{68}$ En referencia a hermanos varones no se cuenta por ahora con más datos y tampoco se los menciona como tales en los listados de Cádiz de 1796 y 1798 , aunque se señala a una hermana de nombre María Luisa. ${ }^{69}$

${ }^{66}$ Relación de los oficiales negros procedentes de las tropas auxiliares. Cádiz, a 4 de abril de 1796, en AGI, Estado, 3, núm. 10.

${ }^{67}$ Copia de la carta del vicario de Dajabón con el arzobispo de Santo Domingo, agosto 11 de 1793, en AGI, Santo Domingo, leg. 1110.

${ }^{618}$ De Juan Francisco de 8 de agosto de 93 en que promete subordinación a los jefes subalternos del presidente. Dajabón, en AGI, Santo Domingo, leg. 1110. A pesar de que el jefe negro señala a un hermano varón en la carta de Vázquez del día 11 de ese mes señala la palabra "hermanos", pudiendo incluir a su hermana María Luisa. Copia de la carta del vicario de Dajabón con el arzobispo de Santo Domingo, agosto 11 de 1793, AGI, Santo Domingo, leg. 1110.

69) Relación de los oficiales negros procedentes de las tropas auxiliares. Cádiz 4 de abril de 1796, en AGI, Estado, 3, núm. 10. El único varón mencionado en esta lista es su ahijado de nombre Eler. Sin embargo, en la relación de 1798 aparecen cuatro varones mayores como familiares de Juan Francisco: Filibert, Bartolomé, Ricardo y Policarpo. Relación de los oficiales negros de las tropas auxiliares. Cádiz a $16 \mathrm{de}$ noviembre de 1798 , en AGS, SG, leg. 7161. 
El matrimonio fue celebrado por Vázquez por instrucciones del arzobispo de Santo Domingo, "tratando con distinciones a la novia para ganar así más la voluntad del novio" y para que se demuestre el modo generoso del gobierno español, "haciendo ver que las promesas ofrecidas se verifican con oportunidad y con el honor característico de la nación". Para ese acontecimiento se le regaló a la novia una porción de varas de seda y medias; al novio se le dieron golas de oro y paño azul para su uniforme y el de sus demás generales, esperando García que con ello los jefes negros creyesen en las demás promesas. ${ }^{70}$

Antes de terminar el año 1793 los hispanos y sus auxiliares se habían apoderado de una parte importante del territorio francés y se podía pensar en una excelente relación entre los dos bandos. ${ }^{71}$ Sin embargo, la realidad no era tan idílica, ya que las autoridades de Santo Domingo veían con recelo a Juan Francisco por las faltas de subordinación y altanería cometidas para con el comandante de Dajabón. Al respecto, el gobernador García apuntaba con cierto temor que "esta arrogante exposición de Juan Francisco nace del conocimiento que tiene de nuestras débiles fuerzas no sólo en Dajabón, sino en toda la larga extensión de la frontera y que sus brazos son precisos para nuestro resguardo". ${ }^{22}$

${ }^{70} \mathrm{El}$ gobernador expone sus disposiciones para vestit algo a lo negros. Santo Domingo a 13 de octubre de 1793, en AGS, SG, leg. 7158, exp. 29.

${ }^{71}$ El gobernador de Santo Domingo instruye sobre haber sido apresado y represado el puesto de la Tenería. Santo Domingo a 25 de septiembre de 1793 , en AGS, SG, leg. 7157, exp. 19.

${ }^{72} \mathrm{El}$ gobernador de Santo Domingo da cuenta de la conducta de Juan Francisco. Santo Domingo a 12 de agosto de 1793, en AGS, SG, leg. 7157, exp. 19; Porro, "Inquietudes", 1993, p. 177.
A pesar del fracaso en la petición sobre las tropas, al año siguiente la recapitulación de las fuerzas del general Juan Francisco arrojaba la suma de 6093 personas, repartidas en diversas compañías por numerosos sitios, como Fort Dauphin con dos brigadas y 878 personas, Saint Susanne con 1317 hombres, Grand Rivière con 2004 soldados y Limonade con 934 personas, entre otras. ${ }^{73}$

Las medallas con el busto del soberano, que se previó entregar a los jefes negros como elementos de ayuda en su adhesión a la causa española, fueron recibidas por el gobernador de Santo Domingo a mediados de febrero de 1794. El envío se componía de tres medallas de oro para los cabecillas de las tropas y doce de plata para los segundos más sobresalientes. La que correspondía a Jacinto fue entregada a Toussaint debido a la muerte del primero. ${ }^{74}$

Acerca de aquellos reconocimientos, el gobernador García envió una carta a Juan Francisco señalando lo siguiente:

General Juan Francisco: valeroso guerrero, el rey mi venerado señor, enterado de vuestro bizarro espíritu, de vuestra lealtad, y de vuestra sumisión, os honra, y condecora con una medalla de oro con su real busto en pública señal del mérito y virtudes con que os habéis señalado desde la época feliz en que yo en su real nombre os admití por su vasa-

${ }^{73}$ Recapitulation de toutes les compagines de l'armee du general Jean François, 1794, en AGS, SG, leg. 7157, exp. 58, núm. 298.

${ }^{74}$ El gobernador de Santo Domingo recibe las medalla de oro y plata para los negros auxiliares. Santo Domingo a 18 de febrero de 1794, en AGS, SG, leg. 7157, exp. 20, núm. 247; el gobernador de Santo Domingo acusa recibo del paquere con la medallas para los jefes auxiliares. Santo Domingo a $18 \mathrm{de}$ febrero de 1794, en AGI, Estado, 14, núm. 86 (1). 
llo y por su súbdito con todos los de vuestro ejército. Esta generosa demostración de un rey tan digno de ser amado os hará conocer las piedades con que sabrá distinguir y premiar oportunamente vuestras acciones, vuestra sumisión, y el arreglo de vuestro ejército, al que exhortaréis para que con su constancia, fidelidad y valor, se hagan todos dignos de un premio, y de una atención que perpetúe su gloria, $y$ asegure su conveniencia. Yo como que os miro con la consideración que habéis merecido espero sabréis corresponder a las piedades del rey, estaréis con la mayor atención a mis órdenes como su representante; y que en la imagen de nuestro soberano tendréis siempre presente su sagrada persona, su piedad generosa, $y$ virtudes de que le ha dotado el Todopoderoso para felicidad de sus vasallos. ${ }^{75}$

Todos estos reconocimientos significaban sólo un cambio de oropel y fueron otorgados únicamente con miras a ganar la simpatía y confianza del negro rebelde, ya que, tal como señalaba el arzobispo, se podían quitar en cualquier momento. Asimismo, como ejemplo de las prerrogativas otorgadas a los caudillos auxiliares, el jefe viajaba en su calesa tirado por seis caballos, lujo que no se daba ni el propio gobernador de Cuba, vistiendo sus mejores galas con la faja e insignia de los oficiales generales de los ejércitos y armada del rey, portando en el pecho la medalla de oro enviada por el soberano, y recibiendo saludos con las armas rendidas en sus visitas a los campos de negros. ${ }^{76}$

75 Carta de Joaquín García al general Juan Francisco. Bayajá a 16 de febrero de 1794, en AGS, SG, leg. 71.57, exp. 20.

${ }^{76} \mathrm{El}$ gobernador de Santo Domingo participa haber logrado la toma de Dondon. Santo Domingo
En 1794, los negros auxiliares seguían cultivando éxitos, sin embargo, la alegría hispana se vio eclipsada cuando Toussaint Louverture abandonó el lado español y se pasó a las filas republicanas junto con otros jefes y sus tropas, los cuales sumaban cerca de 5000 soldados. La noticia de la abolición de la esclavitud por parte de la Convención francesa el 4 de febrero de 1794, así como las desavenencias con sus compañeros Juan Francisco y Biassou, influyeron en su decisión de abandonar en mayo del mismo año las filas españolas. A raíz del abandono de Toussaint y de numerosos seguidores, cambió la relación de fuerzas en la contienda entre franceses y españoles, y en sólo dos semanas el ex auxiliar hispano, recién nombrado comandante de los ejércitos, arrebató a las tropas de Juan Francisco y Biassou una docena de pueblos. ${ }^{77}$ A pesar de las desventajas españolas no todo fue fácil para el nuevo aliado de Francia, pues también las tropas hispanas, en conjunto con los auxiliares, consiguieron algunas victorias. ${ }^{78}$

En julio de 1794, en Bayajá, las tropas de Juan Francisco perpetraron la matanza

a 22 de julio de 1793, en AGS, SG, leg. 7157, exp. 19, núm. 169. Desde antes Juan Francisco ya era admirado y homenajeado por sus colaboradores negros, una demostración de ello era el banquete que le ofrecieron el día 5 de junio en Maribarú cerca de Bayajá, Joaquín García al conde del Campo de Alange. Santo Domingo a 25 de junio de 1792, en AGis, SG, leg. 7150, núm. 221.

77 Franco, Documentos, 1954, p. 30; Di Tella, Rebelión, 1984, p. 85 .

${ }^{78}$ El gobernador de Santo Domingo da cuenta de la expedición que hizo el comandante de Dajabón Esteban Palomares con el negro Juan Francisco y el éxito favorable y buena armonía de nuestros soldados con los auxiliares. Cuartel de Santiago a 11 de agosto de 1794, en AGs, SG, leg. 7160 , exp. 3. 
de cientos de franceses refugiados en el sitio; este acontecimiento, según Joaquín García, agravó la situación interna entre la tropa española y las fuerzas auxiliares. ${ }^{79}$

Para entender la invasión de las fuerzas de Juan Francisco a Bayajá hay que considerar que Francia lo acusaba reiteradamente de llevar a cabo actividades ilícitas, tales como la venta de prisioneros o soldados franceses a diferentes personas de la parte española, lo que era señalado como una acción contraria al derecho. Francia alegaba que los hombres que reclamaba se hallaban al servicio de la República, enganchados en regimientos de tropa y que legalmente no podían ser vendidos o enajenados. En el lado opuesto, y en defensa de Juan Francisco, el gobernador de Santo Domingo contradecía lo anterior diciendo que las tropas españolas (y las auxiliares por extensión) no capturaban soldados, sino únicamente esclavos ladrones y a los que decían ser libres se los trataba como tales. ${ }^{80}$

Sobre el asunto de la actuación de los auxiliares en Bayajá, se señala que el día 7 por la mañana se corrió el rumor de que el mulato Vilat asaltaría la plaza a hora temprana, sin embargo, el que llegó a mediodía fue el general Juan Francisco al mando de 700 u 800 negros armados;

\footnotetext{
${ }^{79}$ Informe de García a Campo de Alange. Sanriago a 1 de agosto de 1794, AGS, SG, leg. 7159, exp. 494.

${ }^{80}$ Correspondencia del gobernador de Santo Domingo, Joaquín García. Santo Domingo a 26 de noviembre de 1795, en AHN, Estado, leg. 3407; Korngold, Citizen, 1979, p. 105, apunta que la venta de negros a los esclavistas españoles se realizaba por parte de los jefes negros Juan Francisco y Biassou. Por su parte, Geggus, "Slave", 1997, p. 140, señala que Juan Francisco mantenía buenas relaciones con los españoles y los proveía de esclavos.
}

entraron violentamente ganando la calle y la plaza principal, cerrando la casa del comandante y dirigiéndose un destacamento para la ocupación de la marina y el puerto. Juan Francisco, acompañado de sus capitanes, entró en la casa del comandante, donde estaban reunidos los jefes españoles, y recriminó la actuación de éstos por admitir en la plaza a varios franceses emigrados, considerados por Juan Francisco como antiguos enemigos que buscaban asilo bajo la corona hispana. Fueron vanos los intentos de hacerle ver al general negro el desacato que cometía contra la real autoridad, y la imposibilidad de cumplir sus demandas de sacar del pueblo a los refugiados en tan poco tiempo. Entonces Juan Francisco dio la señal para que sus acompañantes comenzaran a matar, "y tendiéndose por las calles, no dejaban franceses a vida de cuantos encontraban por ellas". 81

La salida de los auxiliares se produjo con la entrega de la plaza al padre fray Pedro de Cavello, alegando Juan Francisco que la plaza no fue tomada por él sino que los españoles la dejaron desamparada. Como represalia por su actuación se le prohibió que volviese a entrar con su "ejército" auxiliar a alguna plaza, únicamente podría hacerlo libremente acompañado de 80 o 90 de sus soldados armados, número que consideraba como escolta. ${ }^{82}$

${ }^{81}$ El regente de Santo Domingo da cuenta de la horrorosa conducta del general Juan Francisco entrando con sus tropas en Bayajá, ejerciendo hostilidades. Santo Domingo a 15 de julo de 1794, en AGS, SG, leg. 7157, exp. 21, núm. 331; Carta del gobernador de Cuba a 11 de julio de 1794, en Archivo Nacional de Cuba (en adelante ANC), Correspondencia de los capitanes generales, leg. 47, núm. 1.

${ }^{82}$ Certificación que da Juan Francisco al padre Cavello, entrega de la plaza y conclusión de la escena. Ba- 
Debido a la gravedad de los sucesos se abrió un expediente para las averiguaciones pertinentes, pero, sobre todo, las autoridades estaban interesadas en el extravío de los caudales existentes en $\mathrm{Ba}$ yajá, acerca de lo cual el administrador Juan Sánchez notificaba la falta de 48599 pesos, 4 reales, 17 maravedíes, además de numerosas armas, de "cuya extracción o robo los testigos que han sido examinados [culpaban] a las tropas auxiliares del general Juan Francisco". 83

El 14 de octubre de 1795 se recibió en Santo Domingo la notificación de que se había firmado el tratado de paz entre Francia y España, con resultados funestos para la segunda, ya que -contra los pronósticos del arzobispo y del ministro Godoy- debía cederse a los franceses la parte hispana de la isla. ${ }^{84}$ Pero el asunto tuvo mayores consecuencias: en las disposiciones del gobierno francés en relación con la ejecución del tratado, se exigía que Juan Francisco, al igual que los "oficiales a su mando", abandonasen la isla por su condición de militares. ${ }^{85}$

yajá a 13 de julio de 1794, en IHCM, rollo 65, 5-411-1, f. 155; Queda el rey enterado y aprueba las disposiciones tras lo ocurrido en Bayajá el 7 de julio. Madrid a 24 de diciembre de 1794, en AGS, SG, leg. 7161.

${ }^{83}$ Expediente suscitado en Santo Domingo sobre la averiguación de la falta de caudales y demás intereses del rey en Bayajá. Santo Domingo a 11 de abril de 1796, AGI, Santo Domingo, leg. 1038.

${ }^{84}$ El gobernador de Santo Domingo en consecuencia de la real orden de 8 de septiembre dispuso en aquella capital la publicación de la paz. Santo Domingo a 15 de octubre de 1795 , en AGS, SG, leg. 7165, exp. 79, núm. 118.

${ }^{85}$ Esteban Laveaux general y gobernador de Santo Domingo a la Diputación de la República francesa. Fuerre Delfín a 22 de noviembre de 1795 , AHN, Estado, leg. 3407.
Al terminar la contienda armada entre ambas naciones, varios caudillos negros del Guárico también trataron de attraer a Juan Francisco para evitar que se marchase y para que luchase junto a ellos. ${ }^{86}$

\section{Juan Francisco al fin de la guerra}

Para las autoridades hispanas la vida útil del jefe negro dentro de sus filas terminó en el mismo instante en que España cedió el territorio de Santo Domingo a Francia. Al firmarse la paz, el Juan Francisco, que fue esperado con ansias por García tras la invitación a pasar a las filas españolas, o aquel distinguido "negro entre millones de su color", perdió su brillo. Ante acjuellas circunstancias, el trey ordenó que los negros fuesen tratados como pertenecientes a Francia, dejados en la isla e, incluso, dejó entrever que no se respetaría lo estipulado en la real orden del 22 de febrero de $1793 .{ }^{87}$ Sin embargo, ante las presiones francesas, Juan Francisco se convirtió en un vasallo de su majestad católica, otorgándosele ciertos privilegios obtenidos de manera forzada pero, a la vez, excluido de las ventajas y trato de los demás hombres libres blancos por su color y el calificativo de "salvaje" que lo distinguió desde sus primeros combates en La Española.

Con el ocaso militar de Juan Francisco se dio también el inicio del problema que significó para España la evacuación de los

"6 Correspondencia del gobernador de Santo Domingo, Joaquín García con el príncipe de la Paz. Santo Domingo a 22 de diciembre de 1795 , en AlIN, Estado, leg. 3407.

${ }^{87}$ Carta de Godoy a Azanza. Abril 18 de 1796 , en AGl, Estado, 3, núm. 10. 
auxiliares tras el fracaso en aquella aventura imperial, algo no considerado en los riesgos de los planes bélicos. Cuba se mostró reacia a aceptar a aquellos negros rebeldes por el temor de que influyeran con sus ideas en los esclavos de aquella isla. Sin aviso previo, García decidió enviar a las Tropas Auxiliares a Cuba y de ahí a otras regiones del continente americano, una vez dividido el contingente de gente de color, pese a que la idea de Juan Francisco era embarcarse todos juntos hacia algún sitio esperando las promesas del rey y conformando un ejército a su real servicio. Al caudillo se lo envió a Cádiz, en la península ibérica, lejos del escenario del conflicto armado, y donde su imagen como "héroe" para los negros esclavos no fuese conocida y no pudiese ocasionar problema alguno, aunque no se pensó en una estancia permanente sino transitoria mientras se lo enviaba a algún otro sitio, ya sea Centroamérica, Puerto Rico, Florida, Ceuta, Baleares, Caracas, Cartagena de Indias, o incluso, Buenos Aires o la Patagonia. 88

Juan Francisco viajó a Cádiz junto con su esposa, hijas, madre, hermana, etc., un total de 136 personas, divididas en rangos de "amos" y "sirvientes". ${ }^{89}$ Esta división, con remembranzas del antiguo régimen, denota, una vez más, que la lucha de este caudillo en Santo Domingo no persiguió la libertad general de la gente de su clase, sino únicamente intereses personales.

${ }^{88}$ Sobre el asunto de los lugares de envío y las respuestas del ex jefe auxiliar puede consultarse Victoria, "Juan Francisco", 2002, pp. 105-120.

89 Relación de los oficiales negros de las tropas auxiliadoras. Cádiz a 16 de noviembre de 1798 , en AGS, SG, leg. 7161 .
Su estancia en el puerto gaditano transcurrió en algo semejante a un olvido forzado por parte de España. Si bien se le pagaba un salario por sus antiguos "méritos" para con la corona española, las antiguas promesas hechas para ganar su adhesión años antes quedaron lejos de ser lo que Juan Francisco esperaba. A diferencia de lo escrito por algunos autores, es muy probable que el antiguo y arrogante general de las Tropas Auxiliares terminase su existencia en una situación precaria, sin distinción alguna y segregado de la sociedad por sus antecedentes bélicos y condición social. En busca de una mejor retribución económica, Juan Francisco alegaba que las autoridades españolas le habían conferido el grado de general. Tales fueron las dudas sobre el caso que se hubo de preguntar al Ministerio de Guetra si tal se le había conferido, la respuesta resultó negativa. ${ }^{90}$

Sobre el sitio del fallecimiento de este caudillo existen dudas. Se ha señalado que residió en España hasta su muerte ocurrida en 1811, aunque también se indica que residió en Madrid con las mayores comodidades. ${ }^{91}$ Se señala que murió en la península sin especificar lugar, ni fecha, añadiendo de manera errónea que ostentaba el título de Grande de España; ${ }^{92}$ se apunta también que falleció en Cádiz, donde logró amasar una gran fortuna, rodeado de los favores de numerosas muje-

${ }^{\circ}$ Carta del ministro de Guerra a Godoy. San Ildefonso a 28 de julio de 1796 , en AGS, SG, leg. 7161 , exp. 28.

(1) Franco, Revoluciones, 1965, p. 42.

${ }^{2}$ Aimé, Toussaint, 1967, p. 255; 1)i Tella, Rebelión, 1984 , pp. 73 y 85 . Para el caso del título de Grande de España véase Victoria, "Juan Francisco", 2002, p. 123. 
res blancas y conviviendo con lo mejor de los círculos sociales; ${ }^{93}$ del mismo modo, se indica que murió en 1820 mientras ocupaba el puesto de gobernador de Orán, designación que España le dio por sus servicios a la corona. ${ }^{94}$ Otras ideas son que falleció rico y con honores en el puerto gaditano en $1810 ;{ }^{95}$ que terminó sus días en la costa de los Mosquitos, en Centroamérica, ${ }^{96} \mathrm{o}$, bien, que Juan Francisco regresó a Haití para pasar sus últimos días en la isla. ${ }^{97}$

El lugar y año del fallecimiento de Juan Francisco no se saben con certeza. Los temores mencionados que tenían como telón de fondo la esclavitud pudieron ocasionar su evacuación hacia alguno de los sitios propuestos, tal vez Ceuta o Baleares, evitando de esta manera su envío a América, ya que ese destino no era aconsejado por los representantes cubanos en las Cortes de Cádiz, pues aquellos negros habían conocido la libertad y habría que evitar algún "contagio" en las tierras del otro hemisferio. ${ }^{98}$ Cualquiera que haya sido el destino para remitirlo no hay que olvidar que, además de los temores apuntados, los informes del fin de la primera década del siglo XIX señalaban que el gobierno francés, "que jamás ha ahorrado sacrificio alguno para extender su domi-

${ }^{93}$ Korngold, Citizen, 1979, p. 116. Este autor señala que Juan Francisco vestía en su exilio con elegantes y ricos uniformes con elementos de oro.

94 Alexis, Black, 1949, p. 76. Esta idea es imposible, ya que ese sitio fue abandonado por España en 1792.

${ }^{95}$ Benot, Révolution, 1987 , pp. 263-264.

96 Grafenstein, Nueva, 1997, p. 266.

${ }^{97}$ Houdaille, "Negros", 1954, p. 68.

98 ANC, Donativos y remisiones, leg. 521, exp. 22 , en Piqueras, "Leales", en prensa. nación", había ganado con promesas el ánimo de algunos habitantes en su paso por España para que pusieran el sitio a su favor. ${ }^{99} \mathrm{La}$ idea de que de nueva cuenta se pudiesen ganar los ánimos de los negros, pero ahora por parte de los invasores franceses, pudo aligerar en algo su partida, después de tres lustros de una estancia provisional en Cádiz.

\section{CONSIDERACIONES FINALES}

La historia de Juan Francisco puede resumirse en una lucha personal por obtener la libertad en unión de un reducido número de seguidores, más que la de alguien que persiguiese los ideales de libertad para todos los esclavos. Es posible que al principio del movimiento rebelde, la causa o el alegato expuestos para levantarse en armas hayan sido convincentes para él. Sin embargo, su condición de líder lo llevó a tener contactos con agentes de otros intereses que lo quisieron tener en sus filas, lo que despertó en Juan Francisco una mayor ambición personal.

A partir del interés de España en intentar recuperar la totalidad de la isla, aun antes de la declaración de guerra, las autoridades españolas mantuvieron contacto con Juan Francisco tratando de ganar el ánimo del caudillo negro. Éste dejó entonces a un lado los principios que lo motivaron a levantarse en armas y los cambió por las promesas de "libertad, goces y pretrogativas" que los españoles ofrecieron para los negros y mulatos, pero sobre todo, por lo esperado a título personal y para algunos de sus colaboradores.

99 Gazeta del Gobierno, viernes 3 de marzo de 1809, pp. 190-191. 


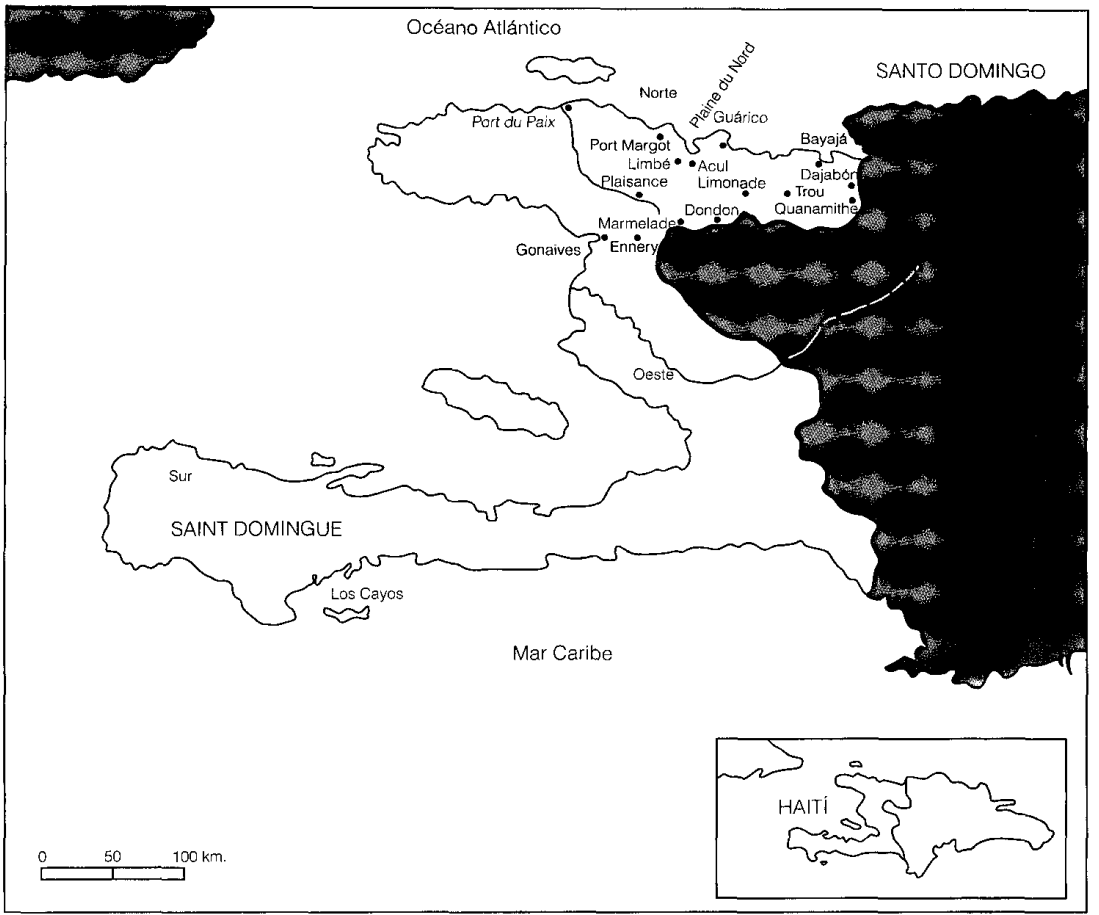

Isla de La Española hacia 1794. Principales sitios mencionados en el texto. Basado en Benot, Révolution, Recuadro: División actual de la isla entre Haití y República Dominicana.

El nuevo aliado de España fue cubierto de elogios, medallas y títulos castrenses sin valor alguno, todo ello con el afán de contar con un líder que motivase a los ex esclavos, aunque éstos, en última instancia, no se beneficiarían del éxito, ya que la corona no comulgaba con los principios revolucionarios de libertad e igualdad.

La historia de Juan Francisco contribuye a conocer algunos pormenores de los tiempos tempranos de la revolución haitiana, sobre todo cuando se señala de manera generalizada que "los esclavos comenzaron a luchar por su propia libertad", ${ }^{100}$ omitiendo facetas de los rebeldes como luchadores por los intereses de la monarquía francesa e, incluso, de los intereses personales que pudo tener cada uno de los cabecillas del movimiento. En la línea de las fuerzas hispanas, los papeles

${ }^{100}$ Rodríguez, "Emancipación", 2001, p. 56. 
desempeñados por Juan Francisco y la corona denotan una unión que perseguía intereses desiguales, donde, a fin de cuentas, las autoridades españolas tuvieron un comportamiento que no correspondía a las promesas ofrecidas, aun cuando éste desdecía por mucho el mentado "modo generoso del gobierno español [...] [y el] honor característico de la nación".

Por otro lado, la imagen del caudillo negro que el devenir del movimiento armado de Saint Domingue atribuyó a Juan Francisco, ayudado en mucho por la misma construcción de líder que de él hicieran las autoridades españolas en su afán por tenerlo en sus filas, contribuyó a que su figura entrase al espacio social cotidiano y engrosara el imaginario colectivo en cierto sector negro del Caribe, convirtiéndose en un modelo a seguir y, por lo tanto, en una figura de atracción de masas. Lo anterior se refuerza con lo acontecido en La Habana a principios de 1796 a su llegada de La Española, cuando las autoridades habaneras impidieron que fuese visitado y festejado por la multitud negra que lo aclamaba, y cuando en 1811 se invocara su figura para tratar de dar fuerza a una conspiración que se gestaba en ese mismo puerto cubano.

La imagen que la población negra del Caribe conservó de Juan Francisco fue la de un esclavo capaz de romper con el modelo de vida impuesto y del cual el caudillo escapó, sin importar que fuese por intereses personales, materiales y protagonistas.

\section{ARCHIVOS}

AGI Archivo General de Indias, Sevilla AGS Archivo General de Simancas
AlIN Archivo Histórico Nacional, Madrid

BN Biblioteca Nacional, Madrid

IHCM Instituto de Historia y Cultura Militar, Madrid

ANC Archivo Nacional dé Cuba, La Habana

\section{HEMEROGRAFÍA}

Gazeta del Gobierno, Cuba.

\section{BIBLIOGRAFÍA}

-Aimé, Cesaire, Toussaint Lowverture. La revolución francesa y el mundo colonial, Academia de Ciencias de Cuba, La Habana, 1967.

-Alexis, Stephen, Black Liberator. The life of Toussaint Louverture, E. Benn, Londres, 1949.

-Benot, Yves, La révolution française et le fin des colonies, Éditions La Découverte, París, 1987.

-Di Tella, Torcuato, La rebelión de esclavos de Haiti, Ediciones de IDES, Buenos Aires, 1984.

-Franco, José Luciano, Documentos para la Historia de Haití en el Archivo Nacional, Publicaciones del ANC, La Habana, 1954.

- Revoluciones y conflictos internacionales en el Caribe, 1789-1854, Instituto de Historia/ Academia de Ciencias de Cuba, La Habana, 1965.

- Historia de la revolución de Haití, Editora Nacional, Santo Domingo, 1971.

, Rebeldías negras en los siglos XVIII y $X I X$, Universidad de La Habana, La Habana, 1975.

-Geggus, David, Slavery, War, and Revolution. The British occupation of Saint Domingue, 1793-1798, Clarendon Press, Oxford, 1982.

S Slave resistance studies and the Saint Domingue slave revolt: some preliminary considerations, Latin American Caribbean Center-International University, Florida, 1983 (Ocasional Papers Series, núm. 4). 
- , "Slave resistance in the Spanish Caribbean in the Mid-1790's" en Gaspar, D. y D. Geggus (comps.), A turbulent time. The French revolution and the Greater Caribbean, Indiana University Press, Bloomington, 1997, pp. 131-155.

-Grafenstein, Johanna von, Nueva España en el Circuncaribe, 1779-1808. Revolución, competencia imperial y vínculos intercontinentales, UNAM, México, 1997.

-Houdaille, Jacques, "Negros franceses en América Central a fines del siglo XVIII", Revista Antropologia e Historia de Guatemala, Instituto de Antropología e Historia de Guatemala, vol. 6, núm. 1, 1954, pp. 65-67.

-James, C. L. R., The Black Jacobins. Toussaint Louverture and the San Domingo revolution, Allison and Busby, Londres, 1982.

-Knight, Franklin W., "The haitian revolution", The American Historical Review, vol. 105, núm. 1, 2000, pp. 103-115.

-Korngold, Ralph, Citizen Toussaint, Greenwood Press Publishers, Connecticut, 1979.

-Ott, Thomas, The Haitian Revolution, 17891804, The University of Tennessee Press, Knoxville, 1973.
-Piqueras, José Antonio, "Leales en época de insurrección. La elite criolla cubana entre 1810 y 1814", Universidad de Salamanca, en prensa.

-Porro Gutiérrez, Jesús, "Inquietudes en la parte española de la isla sobre la sublevación de los esclavos de Saint-Domingue", Rerista de la Universidad de Alcalá de Henares. Estudios de Historia Social y Económica de América, núm, 10, 1993, Madrid, pp. 165-179.

-Rodríguez O., Jaime, "La emancipación de América", Secuencia, núm. 49, 2001, México, pp. 42-69.

-Schoelcher, Víctor, Vie de Toussaint Lowwerture, Édition Karthala, París, 1982.

-Sheridan, Richard, "The Plantation Revolution and the Industrial Revolution, 16251775", Caribbean Studies, Universidad de Puerto Rico, núm. 3, 1969, San Juan, pp. 5-25.

-Victoria Ojeda, Jorge, "Juan Francisco. Jefe de los negros auxiliares de Santo Domingo", tesina, Universidad Jaume I, Castellón, 2002. 